\title{
Forensic Poetics: Legal Documents Transformed into Strange Poems
}

Browsing petitions, lettres de cachets, internment records, and administrative and police documents from the beginning of the eighteenth century at the Bibliothèque Nationale, Michel Foucault confesses in Vie des hommes infâmes that the reading of these archives disconcerts more than any literary text. These documents sealed the fates of ordinary individuals - squandered and abused spouses, disobedient young people - such as JeanAntoine Tousard, who, after being found guilty of committing sodomy and being an atheist, was sent to and confined at the Chateau de Bicêtre on 21 April, 1701. Even though the exhumation of ordinary lives, of secondary actors as opposed to historic memorable figures, has been anchored in recent historiographical debates and in a renewed interest in the archive, ${ }^{1}$ Foucault did not intend to analyse or decipher their meanings but rather to show how they articulated certain norms of their times and reflected the encounter between political mechanisms and discourse. From the material observation of the lives etched into these archives came the idea of a collection - as opposed to a rational classification - which consisted in gathering these "poèmes vies"2 according to specific pragmatic and stylistic criteria in order to restore their sparkle, intensity and violence:

Les documents que j'ai rassemblés ici sont homogènes ; et ils risquent fort de paraître monotones. Tous cependant fonctionnent au disparate. Disparate entre les choses racontées et la manière de les dire ; disparate entre ceux qui se plaignent et supplient et ceux qui ont sur eux tout pouvoir ; disparate entre l'ordre minuscule des problèmes soulevés et l'énormité du pouvoir mis en œuvre ; disparate entre le langage de la cérémonie et du pouvoir et celui des fureurs ou des impuissances. Ce sont des textes qui regardent vers Racine, ou Bossuet, ou Crébillon ; mais ils portent avec eux toute 
une turbulence populaire, toute une misère et une violence, toute une "bassesse" comme on disait, qu'aucune littérature à cette époque n'aurait pu accueillir. Ils font apparaître des gueux, des pauvres gens, ou simplement des médiocres, sur un étrange théâtre où ils prennent des postures, des éclats de voix, des grandiloquences, où ils revêtent des lambeaux de draperie qui leur sont nécessaires s'ils veulent qu'on leur prête attention sur la scène du pouvoir. (Foucault 238)

What drew Foucault's attention to these disparate discourses was that, beyond the contrast between the minuscule wrongs of pitiable lives and the grandiloquent rhetoric, they rejected the hypostasis of the first person narrative, not only since they were reported in the third person singular depriving these men of voices and faces, but also in that their discursive and stylistic heterogeneities elicited a lack of clear generic assignation ("ni quasi-, ni 'souslittérature', ce n'est même pas l'ébauche d'un genre") (Foucault 253).

This ambitious project at the intersection of history and literature, renewing the minor genre of the Lives - a tradition that can be traced back to Plutarch and culminating at the Renaissance -, had sunk into oblivion but fed into the ideas of subsequent French historians, writers and poets. Since the 1990s, literary criticism has indeed noticed a growing interest in the interrelation between archives, life and literature in French cultural production. In the novel, it tied in with the decline of Structuralism and formal definitions, a return to the 'real' resulting from literature's abandonment of the abstraction of the Nouveau Roman that favoured new ways of looking at ordinary lives and the emergence of hybrid works exploiting, amongst other forms, testimonies, archives or photographs. This new paradigm, whose designation remains, amongst critics, debatable ("littérature factographique", 3 "réalisme contemporain", "le récit factuel", "littérature non fictionnelle") is not used by contemporary authors to promote a new form of rationality, one similar to the scientific 
method developed by many nineteenth-century authors. Rather, they tend to incorporate a self-reflexive awareness of the social sciences to move beyond the epistemic oppositions of subjectivity/objectivity, fiction/fact, considering the novel as a space of observation and elucidation ${ }^{5}$ and aligning themselves with Derrida's conception of the archive as a reflection of the real, a central feature of mental lives. ${ }^{6}$ While, for contemporary novelists, venturing into the archives of existing lives shows that there is no need to invent new lives or stories when one can dig into what already exists, contemporary French poets devote themselves to an opposite paradigm: to re-enact or 'redescribe' a wide range of documents (statements alleging sexual assault, testimonies, minutes of war crime reports, etc.), all linked to the public arena, through a process of decontextualization/recontextualization via new layouts, visual arrangements or media. The redescription and the repurposing of these documents aim at creating what French poet Franck Leibovici calls "une poésie forensique"7 in order to recommunicate them in a different way. ${ }^{8}$ While the substantive 'forensic' derives from the Latin forum and alludes to the space of negotiation and truth-finding in the public space of Roman city, any type of text can be potentially considered forensic ${ }^{9}$ inasmuch as it relates to a particular setting, a legal context or a public and political issue:

Par exemple, mettre en partition des chansons et des musiques de propagande djihadiste pour les rendre transportables et étudiables afin d'écrire l'histoire d'un conflit depuis les poèmes qui sont produits ; convertir en .doc des archives scannées du Sénat américain de filibusters, qui étaient en .jpeg, pour pouvoir les rendre manipulables ; mettre en partition chorégraphique des vidéos de milices qui s'entraînent ; republier des minutes de procès pour en faire ressortir une dimension anthropologique. Toutes ces opérations de conversion, de transcription, de 
republication, permettent de montrer le fonctionnement du document, relèvent de l'écriture et sont donc bien pour moi du ressort de la poésie. ${ }^{10}$

In keeping with its tendency towards experimentalism, renewal and the repurposing of found texts, contemporary poetry aims to resort to neither parodistic nor 'deconditioning' methods. Striving for effectiveness, these forensic poetics consist in 'republication', both understood as 'publishing again' and as 'making public again', through the redeployment of “forgotten, invisible, vanished or censured objects as means to produce new significations". ${ }^{11} \mathrm{Such}$ attempts in the Anglo-American contexts can be found in the works of British verbatim playwrights associated with 'documentary theatre' (Nicolas Kent, David Hare, Robin Soans) who all, each time differently, stage verbatim extracts from war crime trials or current affairs $;{ }^{12}$ or, in in the United States, in the work of neo-conceptualist poets such as Vanessa Place, who, while being a criminal appellate attorney, repurposes documents and extracts from her work. ${ }^{13}$ If these practices, in France, do indeed herald a return to praxis and action, an interest that resumed after a hiatus of several decades, the rediscovery and critical reappraisal of the American objectivist poets, a group formed in the 1930s by Louis Zukofsky and comprising Georges Oppen, Carl Rakosi, Lorine Niedecker, Charles Reznikoff, and Basil Bunting, played a significant role in the reconfiguration of French poetry. Reznikoff, who trained as a lawyer before segueing full-time into writing, is known in France for Testimony: The United States (1855-1915): Recitative, which portrays the dark underbelly of America at the end of the nineteenth century. Reznikoff's systematic, factual method consists of copying court records related to violent crimes verbatim and then arranging them as verse. As French poet Emmanuel Hocquard explains, Reznikoff succeeds in making visible facts in their sheer immanence detached from subjective judgments and devoid of sentimentalism, psychologism or rhetoric: 
Reznikoff demande au poète de se contenter de donner à voir, à la manière d'un témoin devant un tribunal, sans chercher à influencer le jugement ou l'émotion du lecteur. Pour cela il met en place un espace neutre, il ménage une distance sans laquelle aucune tentative d'élucidation ne saurait être possible. Cette distance, cet écart, est le (théâtre du) travail poétique, un théâtre de mots puisque la langue est à la fois le matériau et l'outil quotidiens du poète. ${ }^{14}$

This neutral distance between the text and the reader, which echoes the one between the psychoanalyst and the patient, elicits a reflexive space within discourse which leads to a clarification of thought and an objectification of discourse. This method has had a considerable influence on iconoclastic contemporary poets, giving rise to two distinct models of appropriation: one that is in a clear lineage with Reznikoff, is based on an aesthetic understanding of the legal text, and attempts to emphasize its philological aspects (stylistic patterns, emphasis on rhythm as essential criteria of 'literariness'); and another that mainly focuses on the ability to re-enact these materials, to transform them into intellectual technology by prioritizing epigraphical concerns (studies of inscription, scriptural economy, contextual chains and so on). In this article I shall follow these two approaches by questioning the terms and consequences of these engagements through study of the work of Frank Smith and Franck Leibovici. I will show the ways in which these appropriations create new poetic objects that enable us to reconsider the relations between life, discourse and power whilst offering new perspectives on the relationships between literature and politics in French contemporary poetry.

\section{Real Lives Played Out in Few Sentences}


Frank Smith, who trained initially as a radio producer, has since 2010 published a series of books clearly aligned with Reznikoff's verbatim method. Alongside recycling press coverage from English and French newspapers during the Libyan conflict in 2001 in États de faits ${ }^{15}$ and sampling the December 2008 Goldstone report on Gaza in Gaza d'ici-là, ${ }^{16}$ in Guantanamo Smith redescribed the CSRT (Combatant Status Review Tribunal Transcripts), three hundred and seventeen formal interrogations conducted on Guantanamo detainees. Some months after the War on Terror started in the wake of 9/11 in America, the Guantanamo Bay Naval Base became a prison in which several hundred enemy combatants were held. They were allegedly linked to Al-Qaeda, and the U.S. military had accused them without formal charge.

Guantanamo became the theatre of turbulent legal investigations into inhumane treatments relying on torture, physical and psychological violence. In January 2006, responding to pressure from the American press, the Department of Defense released these verbal trials, giving the detainees the possibility of challenging their incarceration in civilian courts. Through the frugal practice of quotation, Smith made tangible these infamies, revealing the most unsayable, intolerable and shameless of them:

Les Américains m'ont battu si violemment que j'ai peur de ne plus pouvoir fonctionner sexuellement. Au point que je ne sais pas si je serai encore capable de faire l'amour à ma femme. Depuis, je suis vraiment très malade, je ne contrôle plus mon urination et mets parfois du papier toilette pour ne pas souiller mon pantalon, 
dit-il encore. ${ }^{17}$

While appropriating the fleeting, strident words etched in these transcripts, Smith offers a specific redescription that can be seen as a translation of one language into language. First, Smith translated the original English transcripts into French, transcripts which themselves, in part, must have been initially recorded in Pashtu, Uzbek and Arabic. Second, Smith effected a translation from one register to another, from one context to another, from the legal to the literary. Through a process of selection, copying and pasting, Smith has turned the large quantity of data into 29 short, compact chapters, each not exceeding six pages.

That referential forms of writing such as legal documents could be recognized for their literary value and despite their original intention is a theoretical (and ethical) problem that has been discussed by Gérard Genette in Fiction et Diction. Genette distinguishes two different regimes: the constitutive regime, which refers to Aristotle's taxonomy and thus includes "la fiction narrative ou dramatique et la poésie", ${ }^{18}$ and the conditional regime, grounded in subjective appreciation and including discarded texts that do not follow the same organization of language marked by the seal of 'literariness', such as testimonies and scientific and philosophical narratives. Yet, in Smith's work, the shift from document to aesthetic is not purely a shift of context, but implies important transformations. Designed to provide an account of the conditions of the Cuban Naval Base, Guantanamo offers a new kind of poetic object that disrupts the categories of law and poetry, fact and fiction, innocence and guilt.

While Guantanamo maintains a clear and referential relation with the original legal transcripts through contextual elements and formal features, Smith has followed a set of specific stylistic criteria which disrupt the horizon of expectation associated with these forms of writing. He has removed decorative and lyrical patterns of expression in favour of a sober, 
clear idiom (plain grammar, descriptive style), arranging some of these statements into free verse. In order to elicit the functional emphasis of the legal mechanism and also to provide a dramatic and narrative quality to the interview, the alteration of pronouns plays a crucial role. In Guantanamo, 'on' appears the most often. As Mark Sanders notes, the use of the impersonal pronoun - the third personal neutral pronoun on, difficult to translate in English both "denotes a hearsay" and suggests that "it destabilizes the conditions of possibility for properly determining the 'combatant' status and the one being interrogated". ${ }^{19}$ This 'hearsay' elicits in fact a type of 'rumor', a polyphony across the poem where one voice takes over from another. Speech is suddenly reduced to an abstract, indiscernible and impersonal line that disrupts hierarchies and identities in favour of a constant process of redefinition. Like Blanchot, Smith rejects both the idea of personology in linguistics (the 'I' as the ultimate foundation) and the Jakobsonian theory of the shifter, described as the emphasis on both the location and the object of reference from a subjective point of view. Rather he gives the primacy to the third person narrative which refers to the neutral and impersonal voice. Blanchot famously analyzed both the paradigmatic and symbolic shift in consciousness between an utterance like "Je suis malheureux" and "Il est malheureux". ${ }^{20}$ While the former example might be seen as what Wittgenstein calls a "private utterance" 21 belonging only to the person uttering it and resolutely incommunicable, the latter generates a sort of distance between language and consciousness. It becomes an external projection of the unfortunate circumstances of one's experience that becomes subsequently tangible for the reader. At the same time, the recursion of this pronoun that permeates the entire book provides an intrinsic rhythmic quality that reminds the reader of the scheme of the epic:

On demande si le jardin était grand ou confiné à une petite arrière-cours. 
On répond que le jardin ne servait qu'à nourrir la famille.

On demande si la maison dans laquelle on habitait, n'abritait que la famille proche ou si d'autres personnes y logeaient également.

On répond que non, il n’y avait que la famille.

On dit que, pourtant, quand on a été capturé, d'autres personnes se trouvaient aussi dans la maison ou les membres de la famille. On demande si c'est bien ça On ne répond pas à la question.(Smith, Guantanamo 16)

Unlike Vanessa Place's Statements of Facts, where victims are indexically mentioned by their name, the lack of nominal identification in Guantanamo reduces victims to single Kafkaeasque initials such as ' $\mathrm{S}$ ' and ' $\mathrm{J}$ '. Like the use of 'on', these letters do not denote a character or a subject but an assemblage. In this context, enunciation is not subordinated to a cogito (a subject as a thought and meaning-producing entity) but is diluted in the explosion of anonymous and collective voices. By preserving anonymity and identification to bypass ethically sensitive issues, Smith succeeds in avoiding the return of psychologism and subjectivity: he represents utterances in their sheer immanence in order to preserve only the eruption of the particular.

As a programmatic quotation from the book suggests - "Nous allons vous poser des questions afin de mieux comprendre votre histoire" (Smith, Guantanamo n.p.) - Guantanomo both raises the very meaning of what is at stake in conducting an interrogation and the way to narrate $a$ story. The two main objectives of an interrogation consist in eliciting information and obtaining confirmation of a particular version of an event. The dialectic of 
Question/Answer dialogue based on the polar Yes/No paradigm, symptomatic of legal mechanics, is made tangible throughout the entire book:

Question: Bonjour

Réponse: Bonjour.

Question: Nous n'avons pas beaucoup d'informations vous concernant, les seuls renseignements dont nous disposons proviennent du « Procès-Verbal Non Classifié ». (...)

Êtes-vous citoyen du Kazakhstan?

Réponse : Oui

Question : Pourriez-vous nous dire pourquoi vous avez quitté, avec votre famille, le Kazakhstan pour l'Afghanistan?

Réponse : Il n’y a pas de travail au Kazakhstan. Gagner sa vie y est difficile.(Smith, Guantanamo 6)

Smith does not, however, attempt to force the reader to sympathize with the detainee, but rather reveals the mechanisms of accusation to the point of absurdity. In Guantanamo, the law is indeed presented as empty, without content to the extent that no one really has any idea of the nature of guilt: one detainee asks the interrogator "Il y a une question à laquelle vous n'avez/pas répondu. Une fois de plus, j'aimerais savoir d'où/le greffier tire ses accusations/Elles sont fausses"(Smith, Guantanamo 150); another protests against the president of the tribunal, "Cette femme, avec ses cinq ou six/accusations, j'aimerais vous demander, où est-ce qu'elle a déniché ces informations-là ? Est-ce qu'elle détient/la moindre 
preuve ?" (Smith, Guantanamo 130). That the law can only be expressed by a given mechanism, and that the object of the accusation always remains unknowable, reveals a sort of transcendence. This idea clearly echoes Kant's theory of law as a pure form of universality and moral imperative. For Kant, the law is seen as the highest instance and is not connected to sensible or intelligible objects as in Plato, but instead to practical reason. In that sense, the law is not linked to an internal process that would reveal to human beings which objectives to follow to be good. It is external, as it provides a form that one must follow to be moral. Gilles Deleuze has analyzed the nature and the consequences of this imperative in regards to guilt through the identification of three paradigmatic elements: its a priori aspect ("la culpabilité doit être l'effet l'a-priori qui correspond à la transcendance, pour tout ou par chacun, fautif ou innocent”); its necessary aspect ("la loi n'ayant pas d'objet, mais étant pure forme, elle ne peut pas être du domaine de la connaissance, mais exclusivement de la nécessité pratique absolue"); and, finally, its performative aspect ("la loi ne se détermine qu'en s'énonçant, et ne s'énonce que dans l'acte du châtiment"). ${ }^{22}$ Through redescription, Smith makes tangible, on numerous occasions, this link between the law, guilt and what is unknowable, and the performative aspect of utterances culminating in nonsense:

Président du Tribunal: Je n'ai plus de questions, Quelqu'un voudrait interroger le détenu? Détenu : il y a une question à laquelle vous n'avez pas répondu. Une fois de plus, j'aimerais savoir d'où le greffier tire ses accusations. Elles sont fausses. Président du Tribunal : C'est le gouvernement qui a fourni ces informations au greffier, et le greffier les présente pour le gouvernement. Nous ne savons pas 
exactement d'où elles proviennent pour le moment. souvenez-vous, le greffier a indiqué qu'elle avait des informations classifiées à présenter. Il nous incombe de considérer les informations, les commentaires et les déclarations que vous fournissez tout autant que ce que nous présente le gouvernement. Détenu : Je suis une petite personne. Bien entendu, c'est votre travail, et c'est vous qui décidez. Mais je pense à ces cinq ou six allégations. Si la moindre d'entres elles était crédible, ça serait moins bizarre. Mais elles sont toutes si fausses! Personne n'a le temps de nourrir sa famille tout en faisant ce que vous m'accusez d'avoir fait! (Smith, Guantanamo 150)

The repurposing of these legal documents into a poetic context reveals a tension between, on the one hand, a fraudulent and manipulative use of language within the legal machine and, on the other, ordinary language, the natural communication that brings people together. The socalled objectivity of the legal system confronts the collective subjectivities and loses its currency with its lack of clear evidence, suggestions and inconsistencies. What is given to read is a dismantling of the mechanisms of the legal arena that elicit how it constantly informs and misinforms, directs and redirects the investigation. What this nonsense reveals is a political question that elicits the expression of two modes of desire: the transcendence of power, with its mechanisms of registration and economy of punishment; and the immanence of the detainee and their hopes. The final chapter makes this link particularly tangible: 
Président du Tribunal: Où voulez-vous aller?

Détenu: Je voudrais aller aux États-Unis. Me rendre aux États-Unis, c'est ce que je souhaiterais le plus au monde. Et si les États-Unis ne m'acceptent pas, alors je voudrais rentrer chez moi, en Ouzbékistan. (Smith, Guantanamo 152)

This final statement invites the reader to generate a differential reading of the entire book: it does not invite an ironic or cynical reading, but reflects how the legal machinery has impacted the consciousness of the detainee who seems to have forgotten that he is currently on American soil. It reveals an active mode of existence that rejects the slavery of passive affection (static suffering associated with victimhood) in favour of an active affection (a power to act) which elicits a reexamination of the relations between victim and oppressor, power and desire. Through a process of defamiliarization and a transformation of the original materials, Smith invites the reader to experience how the true is a moment of the false, how falsification elicits effects of truth to such an extent that this impermeability abolishes distinctions between fictional and factual regimes. What this poetic object reveals is an artistic artefact that becomes a tool to unravel new representations of public issues. The shift from the legal to the literary masks two central points, however: first, the chronology and progression of the trial (frequent analepses, lack of contextual features) whose advent is in itself the event; second, the hierarchies, agencies and actors involved on the stage of power, who all become neutralized. Through the alteration of pronouns, the anonymization and versification, Smith draws attention to the intrinsic strangeness of legal documents but, through redescription, he makes strategic use of them, bringing to the fore ethical and emotional perspectives on public issues. 


\section{The Working of Power on Lives}

In a different way, Franck Leibovici considers redescription to be a technology of writing within the frame of an action theory that enables the construction of salient institutional ecosystems. Rejecting the idea of a language cut off from wordly purposes, Leibovici's poetry consists in repurposing found texts whilst providing new modes of classifying data. ${ }^{23}$ In collaboration with Julien Seroussi, a sociologist, legal scholar and specialist in International Criminal Justice, in 2016 Leibovici published a large volume entitled Bogoro, referring to the 'Bogoro massacre' which occurred on February 2003. The assault was an attack on the Bogoro village in the Democratic Republic of Congo by the Nationalist and Integrationist Front and the Front of Patriotic Resistance of Ituri. These fighters, who also included children, attacked Bogoro with spears, arrows, mortars, automatic weapons and machetes, killing at least 200 civilians, imprisoning survivors alongside corpses, and using women and young girls as sexual slaves. Germain Katanga and Mathieu Ngudjolo Chui, two rebel leaders, have since been charged by the International Criminal Court (ICC) with war crimes and crimes against humanity. Drawing entirely on the legal transcripts and materials of the first trial held at the ICC in 2007, Bogoro aims at redescribing the scriptural economy of the document to reveal its mechanisms, ecology and process:

bogoro suit la chronologie d'un des premiers procès de la cours pénale internationale à la haye $(. .$.$) le texte est compose de quatre parties: la première partie donne la parole$ aux témoins du procureur, anciens enfants-soldats, à la fois victimes de la guerre et participants actifs aux massacres; la seconde donne la parole aux victimes; la troisième, aux témoins de la défense ; la quatrième rend compte, dans un retournement 
un peu théâtral, de la crédibilité des témoins telle qu'elle fut évaluée dans le jugement de la cours. ${ }^{24}$

While the trial follows the Audi Alterem Partem principle ('listen to the other side'), which consists in giving a party the right to confront the witnesses for the defense in order to challenge the evidence presented by the other party, Bogoro focuses less on the judgement or the conclusion of the trial than on the verbal interactions and the functioning of the legal arena. In that sense, Leibovici and Seroussi neither seek to provide a denunciation of the massacre, nor to intervene, nor to add to or comment on any aspect of the trial, but instead to offer a sketch (based on scale, displays, mobility) of the dysfunctional stage of power. Leibovici maintains a significant number of formal features present in the editorial architecture of the transcripts: the format of the book is analogous to the original dimensions of the legal documents; the documents include 'case numbers' or 'headings' such as 'ICC01/04-01/07-T-220-Red-FRA WT 22-11-2010 1/78 RM T'; the numbering is based on the original stenographic court reports, so that the reader notices that, throughout the trial, the numbering shifts from 1-25 to 1-28. All these elements play an indexical function $-\mathrm{a}$ form of 're-familarization' - which reminds the reader of the official transcripts. As with Smith, Leibovici's redescription implies a process of selecting utterances and then reconfiguring them. First, Leibovici has gathered elements that were initially disjointed to create two narratives that in fact belong to the same thread: the former relates to the attack committed in Ituri (in black in the text), and the latter to the technological glitches of the trial which disrupted its rules and operations (in grey in the text). Second, he has added a tabular system ('tags' in red in the text) throughout the transcripts and created an index following Zukofsky's alphanumerical device - a redescription of a redescription - that enables the reader to check, compare, and relate disparate elements in the reading process. 
Through redescription, Leibovici is interested in revealing the scenography of the trial, and especially the disruption at play during the trial. Many aspects obfuscate the workings of the law during this trial, which impinges on positions and interpretations. As the barristers and judges speak to the witnesses, the translation is piped into the headphones of the witness and the accused in a language that they choose; the answer is then piped in French to the court and public gallery. While some parts of the translation proceed smoothly, there are many problems caused by technological glitches. These include, "(se corrige l'interprète)", “l'interprète swahili-français: monsieur le président franchement, la/cabine a des difficultés à comprendre, là (...) il faut que/vous parliez lentement, comme vous le faites, peut-être plus fort parce que ce n'est/pas aussi simple pour l'interprète d'interpréter vos propos que lorsqu'il s'agit/de raconteur des événements" or "et des bourdonnements extrêmement gênants". What matters is thus neither capturing paralinguistic signals, such as intonation and pitch, nor focusing on extralinguistic features, such as smiles, nods, the raising of eyebrows, and so on, but dramatizing the scenography of the trial:

22 (recours à un pseudonyme, altération de sa voix distorsion de

23 son image ; huit clos lorsqu'il entrera et sortira de la

24 salle d'audience.)

8 l'installation d'un rideau permettant d'éviter tout contact visuel entre le témoin 0280

9 et les deux accusés, les accusés verront sur leur écran le visage $\mathrm{du}$

10 témoin. (Leibovici and Seroussi 19) 
The division of segments is not based on the delivery or on units as in conversation analysis, although it happens that after a long pause the stenographer goes back to the following line, but, rather, on the amount of speech allocated per line. The duplication of the layout and its alteration has three functions: first, the fact that the numbering breaks with chronological and rational succession reveals what has been selected and deleted by Leibovici. Second, the cleaning of certain units and their selection dramatizes some salient elements of the interaction to the detriment of others, considered by the poet as secondary. Third, the discrepancy between syntactic/rhythmic and graphic units - the presence of blank spaces which reflect or break speech - unavoidably reminds the reader of the formal aspects of poetry:

13 gens pleuraient. Ils étaient découpés en machette.

14 par la suite, vers le soir, les pillages, les crépitements des balles ont cessé. j'avais pensé

16 que tout était fini. (Leibovici and Seroussi 163)

Beyond the depiction of violence and the series of technological glitches that obfuscate the workings of the law, the cleansing effect of the original transcript reflects the numerous cultural and linguistic obstacles faced by the judges and other participants. Although the judges did their best to avoid ethnocentric or neo-colonialist positions and interpretations, Leibovici's redescription reveals the distance that separated the Western apparatus of justice grounded in rational reasoning from the cosmogony of the witnesses and victims. Notions of space, age, kinship, magic and fetish are not easily tackled and barely approximate to the idea of a global justice. The arena is, indeed, repeatedly confronted with linguistic ambiguities to 
the extent that lawyers constantly reiterate or rephrase questions failing to take into account the wider social context and the embedding of ideology in language:

24 q. monsieur le témoin, qui...qui était la personne qui vous donnait ces fétiches?

25 r. il n’y a pas une personne spécifique qui était chargée de nous donner les/

1 fétiches. c'était une personne de bonne volonté. un villageois qui est dirigé par son

2 esprit (...).(Leibovici and Seroussi 32)

What this redescription discloses is an anthropological bias in relationship to language. Claude Lévi-Strauss, after Marcel Mauss, called this "mana"; that is, an entity that is so general in language that it entails the most diverse signifiers. The encounter between the court and the participants thus unmasks two conceptions of language: one that is referential, autonomous, indexical; and another that is a "signifiant flottant" 25 and that cannot be separated from a context, a tribe or a community and that has a psychological-cultural meaning. This split between two regimes of significance signals an imbalance between knowledge/language, human being/ world, the individual/ the institution, oral culture/literate culture. The result raises the issue of truth and reconciliation. The Court struggled to determine the level of responsibility of participants for their crimes. It is partly because the conditions of felicity of a testimony are not the same as in Europe: in Ituri, a witness who asserts that they are telling the truth, tells the truth of his group, which suggests that he would describe the events experienced by his group whilst not necessarily being a direct witness. The same applies to toponymical or topographic descriptions that also undermined the charges laid by the prosecutor against the accused. ${ }^{26}$ In addition, judges did not consider that fetishes (power objects, charms, spells) would play such a significant role alongside the 
military and the political aspects, nor that witnesses would refuse to testify for fear of the fetishes.

Yet this bias about the characterization of the mode of liability with regard to Germain Katanga was challenged within the legal arena, creating a conflict not only between historical and legal evidence, "les conclusions factuelles" and "les conclusions juridiques", but also between two conceptions of writing that the last chapter of Bogoro reveals. This gap elicits two distinct modes of liability, whether ones refers to 'Common Law' (rooted in the legal system of England) or the 'Roman law' (referring to the legal system of Ancient Rome). In the first instance, at the end of their inquiry the prosecutor delivers a narrative to the judges. If the narrative is reliable and resists the counter arguments of the defense, the defendant is convicted. In this paradigm, all the depositions are recorded and typed by a stenographer, to whom the judge constantly refers. In this trial, however, evidence was not always reliable as the prosecutor mainly focused on testimonies, in themselves hardly credible (no basis for findings beyond reasonable doubt). That is why, after the closing arguments of the parties, the Belgian judge Van den Wyngaert was unable to find sufficient evidence that Katanga had served as a military commander and acquitted him as an 'indirect perpetrator'. In his dissenting opinion, the French Judge Bruno Cotte considered the trial unfair, lessened the allegations against Katanga by accusing him of facilitating the supply of weapons used by Local Ngiti militia, and convicted him pursuant on the basis of article 25(3) of the Rome Statute. The chamber concluded that Katanga was found guilty of four counts of war crimes (murder, attacking a civilian population, destruction of property, pillaging) and one count of crime against humanity as the last document of Bogoro testifies. This reveals two different modes of liability based on two approaches to writing: while, in Common Law, truth is based on the juxtaposition of transcripts that play a referential role, in Roman Law truth is not based on recordings or transcriptions but on reformulations and on the 'ultimate conviction' of the 
judge who summarizes and dictates statements to the court clerk. In redescribing these transcripts, Leibovici reveals the theatre of the conflict with the actors, agencies, disruptions and upheavals that shape human action and influence decisions based on the scriptural economy of these documents. In this respect, Rahma Khazam is right to draw a parallel between Leibovici's practice and what Benjamin Buchloh calls "the aesthetic of administration", a practice located in 1960s Conceptual Art according to which artists aimed to "administrer le travail et la production (plutôt qu'à produire)". ${ }^{27}$ Leibovici’s work can be indeed thought of in these terms when he explains that “écrire, ce n'est plus du tout produire des énoncés mais c'est essayer de reprendre plus généralement toute la chaine de l'opération d'écriture de l'amont à l'aval (...) reconnecter des éléments disparates : champs du savoir, expériences. Cette reconnexion rend possibles des gestes qui étaient empêchés jusqu'alors"(Leibovici and Terroni, "Sur quoi opère l'art"). For Leibovici, the poetics lies in the invention of a new apparatus. By resorting to different scales and visual organization to classify the flow of information, the poetic object points towards ethical, historical, legal and linguistic spaces that figure and translate logical multiplicities. Through redescription, Leibovici invents a new poetic object which seeks to represent, from the inside, how the legal arena operates, how actors perceive and categorize events. This 'emic' paradigm, as opposed to the etic one that uses external categories to analyze a situation, only comes from the insider's view of reality and provides a sort of immanence that shapes the conditions of existence.

In an age of post-truth politics characterized by falsifying of facts and instant emotions, the repurposing and redescription of legal texts in poetic contexts provides an antidote to contemporary modes of subjectification. By virtue of retelling, contemporary French poets aim at endowing their readership with a new intellectual and perceptual 
apparatus to tackle the political issues of our time. There is no doubt that the redescription of these forensic texts generates a shift from a 'matter of fact' to a 'matter of concern', but it is clear that these poets face a new intellectual, ethical and creative challenge: how to shift towards the politics of things to re-map politics? How to create an efficient 'object-oriented' democracy? Bruno Latour has called for the emergence of a Dingpolitik, as opposed to the current Realpolitik; that is, the creation of a space that is no longer static or based on a separation between the object and the thing but that involves parties, people and things assembled. Inventing new techniques to represent information - a new object - that would both combine the assemblage and the assembly, the object and its agency, but also raise a public issue, seems to have become an aim for many contemporary artists seeking to provide a new representation of the political. ${ }^{28}$ As Leibovici explains, the repurposing of legal texts into a poetic context enables him to enhance what the law considers residual or secondary within its mechanisms of production:

alors que le droit travaille à arracher une affaire de ses contingences anecdotiques pour le rattacher à des textes et des catégories qui permettront de la qualifier juridiquement, les poétiques forensiques visent, en parallèle à ces transformations et ces qualifications, à faire surgir des acteurs inattendus, qui peuplaient ces écologies jusqu'alors invisibilisées, pour modifier la composition de l'arène du tribunal et augmenter les populations convoquées $[\ldots]$ voir comment des documents sont gros d'une population, et de quoi est faite cette population.(Leibovici and Terroni 35)

Whether it consists in 're-describing' or 're-editing' a document by other means by following specific modalities (musical scores, for instance) or 're-transcribing' audio recordings via the tools of conversation to slow down and make tangible aspects seen but unnoticed, these 
practices seek to invent new regimes of visibility of the political. Through their works, these two poets show that redescription is an inquiry in itself. If the epistemologies of law differ from poetry, the work of these two poets propose that new forms of discourse can be created when disciplines come together. By transforming the properties of these transcripts, Smith shows that poetry enables the reader to generate a critical distance towards contemporary modes of subjectification as his work gives rise to a powerful irony directed at the credulity with which prevailing story-telling is accepted. Leibovici who, by contrast, does not transform these documents to produce a new text, reveals that redescription raises the issue of accountability and liability. Influenced by the techniques of ethnomethodology, his poetry consists in redescribing the organization of legal activities by making them visible and reportable. In doing so, he shows how new layouts of these documents inform our interpretation of them, bringing our attention to elements seen but unnoticed, to the often mundane interactions and contradictions that occur in the legal arena. In both cases, these practices aim neither at 'aestheticizing' these legal texts nor at revealing their intrinsic poetic values according to predetermined and traditional aesthetic categories. Aesthetic experience is here understood in pragmatic terms, that is to say in relationship to experience situated in practical and social life. By not separating aesthetic from intellect, Smith and Leibovici show, like John Dewey, that aesthetic experience is based on observation and cognition. Reading these texts implies reflective action, engagement with the world and distance. Of course, the book is not the only space in which the assemblage and assembly can coincide: these poetic documents, which can be interpreted through a live performance, read in a museum or simply exhibited, ${ }^{29}$ recreate hybrid agoras through the convergence of political, symbolical and material assemblages. These legal documents, transformed into strange poems, not only reveal the workings of power on lives and the discourses which come out of them, but also 
make tangible, perhaps for the first time, the disorder, sorrow and noise of the infamies of our time.

Jeff Barda

Murray Edwards College, Cambridge

${ }^{1}$ Interest in the liminal figures judged or forgotten by history was the result of the Annales school and Structuralism's dismissal of biography. In 1970, Carlo Ginzburg coined the concept of "microhistory", emphasizing the need to focus on the smaller units of society as opposed to generalizations and holistic narratives ("macrohistory"). In The Cheese and the Worms, he famously investigated the life of a single sixteenth-century miller (Baltimore: The Johns Hopkins University Press, 1980 [1976]). 2 “qu'il s'agisse de personnages ayant existé réellement; que ces existences aient été à la fois obscures et infortunées; qu'elles soient racontées en quelques pages ou mieux quelques phrases, aussi brèves que possible ; que ces récits ne constituent pas simplement des anecdotes étranges ou pathétiques, mais que d'une manière ou d'une autre (parce que c'étaient des plaintes, des dénonciations, des ordres ou des rapports) ils aient fait partie réellement de l'histoire minuscule de ces existences, de leur malheur, de leur rage ou de leur incertaine folie; et que du choc de ces mots et de ces vies naisse pour nous encore un certain effet mêlé de beauté et d'effroi." M. Foucault, "La vie des hommes infâmes", in Dits et Ecrits, Vol.3 (Paris: Gallimard, 1994), 239.

${ }^{3}$ M.-J Zenetti, Factographies. Pratiques et réceptions des formes de l'enregistrement à l'époque contemporaine (Paris: Garnier, 2014).

${ }^{4}$ L. Ruffel, "Un réalisme contemporain : les narrations documentaires", Littérature, 166, 12, 2012: 1225.

${ }^{5}$ See I. Jablonka, L'Histoire est une littérature contemporaine. Manifeste pour les sciences sociales (Paris: Points, 2017).

${ }^{6}$ J. Derrida, Mal d'archive : Une impression freudienne (Paris: Galilée, 2008). 
${ }^{7}$ F. Leibovici, "Forensic Poetics" in Document, Fiction et droit dans l'art contemporain, J. Arnaud, B. Goosse eds, (Presses Universitaires de Marseille, Hors collection, 2015), 302- 317.

${ }^{8}$ See F. Leibovici, des documents poétiques (Al Dante, Questions Théoriques/Forbidden Beach, 2007).

${ }^{9}$ See J. Olson, Forensic Linguistics (London: Continuum, 2008), 1 and see for a list of 'forensic texts', $128-54$.

${ }^{10}$ See also F. Leibovici and C. Terroni, “Sur quoi opère l'art: Entretien avec Franck Leibovici”, 14/10/2016, available on the following link, http://www.laviedesidees.fr/Sur-quoi-opere-l-art.html (accessed on $21^{\text {st }}$ January 2017).

${ }^{11}$ See M. Villenueve and V. Bobin eds, Republications (Berlin: Archive Books, 2016), 13.

${ }^{12}$ W. Hammond and D. Steward,eds, Verbatim, Verbatim: Techniques in Contemporary Documentary Theatre, (London: Oberon Books, 2008).

${ }^{13}$ See for instance, V. Place, Tragodía 1: Statement of Facts (2010), Tragodía 2: Statement of the Case (2011), Tragodía 1: Argument (2011) all published by Insert Blanc Press. See also V. Place, The Guilt Project: Rape, Morality and Law (New York: Other Press, 2015).

${ }^{14}$ E. Hocquard, "La Bibliothèque de Trieste”, in Ma haie, (Paris: P.O.L., 2001), 28.

${ }^{15}$ F. Smith, États de faits, (Paris: Editions de l'Attente, 2013).

${ }^{16}$ F. Smith, Gaza d'ici là (Paris: Al Dante, 2013).

${ }^{17}$ F. Smith, Guantanamo (Los Angeles : Les Figues Press, 2014 [2010]), 70.

${ }^{18}$ G. Genette, Fiction et diction (Paris: Seuil, 1991), 26.

${ }^{19}$ M. Sanders, "Introduction" in Guantanomo, 2014, vii.

${ }^{20}$ M. Blanchot, La part du feu (Paris : Gallimard, 1949), 29.

${ }^{21}$ L. Wittgenstein, Philosophical Investigations, transl G.E.M. Anscombe, P.M.S. Hacker, Joachim Schlute, $4^{\text {th }}$ ed. (Chichester Wiley-Blackwell, 2009), § 243, p. $95^{\mathrm{e}}$.

${ }^{22}$ G. Deleuze, Kafka: Pour une littérature mineure (Paris : Editions de Minuit, 1975), 80-81.

${ }^{23}$ See for instance, F. Leibovici, Portraits chinois (Romainvilles: Al Dante, 2007).

${ }^{24}$ F. Leibovici, J. Seroussi, Bogoro (Paris: Editions Questions Théoriques, 2016), 349. Leibovici’s quotations are reproduced as they appear, i.e. with lower case letters even after full stops. 
${ }^{25}$ Claude Lévi-Strauss, "Introduction à l'Euvre de Marcel Mauss" in M. Mauss, Sociologie et anthropologie (Paris, PUF, [1950] 1999), 49.

${ }^{26}$ See "plan" in Bogoro, 34.

${ }^{27}$ R. Khazam, "Introduction” in Une poétique pragmatique : considérations sur l'œuvre de Franck Leibovici, eds R. Khazam, (AICA, Presses du réel, 2018), 30.

${ }^{28}$ B. Latour, "From Realpolitik to Dingpolitik, An introduction to Making Things Public" in Making Things Public: Atmosphere of Democracy (Cambridge: MIT Press, 2005), 3-34.

${ }^{29}$ Leibovici and Seroussi presented muzungu, from Bogoro, at the Bunkier Sztuki Centre for Contemporary Art in Krakow in the spring of 2016. Muzungu consisted in hanging all the pieces of evidence (administrative documents, photos, diagrams, transcripts) on A4 size paper. Leibovici used colour codes and keywords to make salient items of the trials that were overlooked during the trial. As Leibovici explains, "les visiteurs sont invités à proposer une composition nouvelle d'éléments hétérogènes, offrant ainsi une amorce des narrations des événements hétérogènes, offrant ainsi IS THIS REPETITION DELIBERATE ? une amorce de narration des événements peut-être inattendue et une nouvelle représentation de l'affaire. de cette manière, ils se retrouvent, d'une part, dans la position des juges au moment de la délibération, en refaisant les gestes de réarticulation des éléments, mais ils se trouvent également, d'autre part, dans la position du commissaire ou du scénographe, puisque ce sont eux qui composent chaque portant, et que ces portants mobiles viennent peu à peu constituer l'exposition", F. Leibovici and V. Bobin, "Entretien avec Franck Leibovici” in Une poétique pragmatique : considérations sur l'œuvre de Franck Leibovici, 168. 